\title{
Zirconium Bis(Amido) Catalysts for Asymmetric Intramolecular
}

\section{Alkene Hydroamination}

\author{
Donald A. Watson, Melanie Chiu, and Robert G. Bergman \\ Department of Chemistry, University of California, Berkeley, California 94720-1460, \\ rbergman@berkeley.edu
}

\begin{abstract}
In situ combination of diphosphinic amides and $\mathrm{Zr}\left(\mathrm{NMe}_{2}\right)_{4}$ results in the formation of chiral zirconium bis(amido) complexes. The complexes are competent catalysts for intramolecular asymmetric alkene hydroamintion, providing piperidines and pyrrolidines in up to $80 \%$ ee and high yield. This system utilizes an inexpensive zirconium precatalyst and readily prepared ligands and is the first asymmetric alkene hydroamination catalyst based upon a neutral zirconium bis(amido) complex.
\end{abstract}

The development of catalysts for intramolecular asymmetric alkene hydroamination has been the subject of intense investigation over the past 15 years. $1,2,3,4,5$ While considerable advances have been made using catalysts containing a variety of metals, no general solution has emerged. To date, catalysts based on Group 3 and lanthanide metals have shown the most promise for unactivated alkenes. ${ }^{1,2,3}$ However, even within this class only a small number (4) of highly enantioselective reactions (>90\% ee) have been reported. ${ }^{3 \mathrm{c}}$ Thus alkene hydroamination remains an open area of research.

Recently, Schafer $^{6}$ (and subsequently Livinghouse ${ }^{7}$ ) reported that neutral Group IV bis (amido) complexes bearing achiral ligands are competent catalysts for intramolecular alkene hydroamination. Our group has previously reported that closely related catalysts containing chiral dialkoxide and diamide ligands are effective in intramolecular allene and alkyne hydroamination. ${ }^{8}$ We decided to explore the possibility that these types of chiral complexes could be applied to asymmetric alkene hydroamination. Herein, we report the first examples of asymmetric, intramolecular alkene hydroamination catalyzed by Group 4 bis(amido) complexes. ${ }^{9}$ The reported catalysts employ readily available chiral ligands and provide enantioselectivities of up to $80 \%$ ee.

Having previously demonstrated that in situ combination of various diamines or diols and Group IV tetrakis(dimethyl)amides provides competent hydroamination catalysts, ${ }^{8}$ we screened various combinations of these compounds as catalysts in the cyclization of $\mathbf{1}$ (eq 1). 10,11 In an effort to develop a practical catalyst, we focused exclusively on commercially available or readily prepared diols, diamines and aminoalcohols (Table 1). ${ }^{12}$ Although enantioselective catalysts based on titanium and hafnium ${ }^{13}$ were also identified, the zirconium catalyst prepared by combination of diphosphinic amide $3 \mathrm{c}^{12 \mathrm{c}}$ and $\mathrm{Zr}\left(\mathrm{NMe}_{2}\right)_{4}$ (entry 11) proved significantly more enantioselective than others that we studied. Under unoptimized conditions (see footnote, Table 1), pyrrolidine 2 was obtained in $67 \%$ ee and excellent yield. Given this initial promise, we elected to explore additional ligands of the same general structure. 


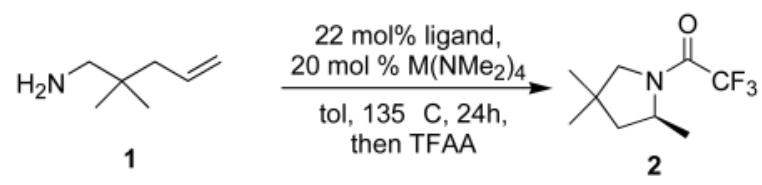

(1).

A series of diphosphinic amides was prepared using one of two short synthetic sequences. ${ }^{14}$ These ligands were investigated in the cyclization of $\mathbf{1}$ (Table 2). Ligands containing the cyclohexanediamine backbone proved to be the most selective (entries 1-5). Variation of the phosphorus substituent (R) had pronounced effects on catalytic activity. The ortho-tolylcontaining ligand 13a gave catalytically inactive complexes (entries 6), while the 3,5-bis (trifluromethyl)phenyl-substituted ligand 13b decomposed when exposed to the $\mathrm{Zr}\left(\mathrm{NMe}_{2}\right)_{4}$. Ligands containing other electron-deficient arenes proved more stable to the reaction conditions, but did not provide improved catalysts (entries 9 and 10). The addition of electrondonating groups did improve catalyst performance in the cyclization of $\mathbf{1}$. The paramethoxyphenyl-containing ligand 13e provided slightly higher enantioselectivity. The more sterically demanding ortho-methoxyphenyl group in $\mathbf{1 3 f}$ provided even higher selectivity, but at the cost of slightly diminished reactivity. Among the ligands screened, the best proved to be 3,5-dimethylphenyl-substituted ligand $\mathbf{1 3 g}$ (entry 12). This ligand provided the best combination of reactivity and enantioselectivity, providing $\mathbf{2}$ in $75 \%$ ee and $99 \%$ conversion under these unoptimized conditions. Larger meta substituents did not improve the catalyst performance (entry 13).

Having identified a promising ligand, we sought to further optimize the cyclization of $\mathbf{1}$ using the combination of $\mathbf{1 3 g}$ and $\mathrm{Zr}\left(\mathrm{NMe}_{2}\right)_{4}$ as catalyst. Neither variation of the solvent ( $\mathrm{PhH}, \mathrm{Ph}-$ $\mathrm{F}, \mathrm{Ph}-\mathrm{Cl}, 1,4$-dioxane and pyridine), nor the addition of basic $\left(\mathrm{LiNMe}_{2}\right){ }^{15}$ or acidic $\left(\mathrm{HEt}_{2} \mathrm{O} \cdot \mathrm{B}\right.$ $\left.\left(\mathrm{C}_{6} \mathrm{~F}_{5}\right)_{4}\right)$ additives affected the yield or ee of the product obtained in the reaction. Lowering the reaction temperature did improve the ee, and under optimized conditions, $\mathbf{2}$ was produced in $95 \%$ yield and $80 \%$ ee in $24 \mathrm{~h}$ using $20 \mathrm{~mol} \%$ each of $\mathbf{1 3 g}$ and $\mathrm{Zr}\left(\mathrm{NMe}_{2}\right)_{4}$ (Table 3 ). Lowering the catalyst loading to $10 \mathrm{~mol} \%$ provided 2 in $91 \%$ yield and identical ee in $48 \mathrm{~h}$.

Table 3 illustrates the substrate scope of the asymmetric hydroamination reaction using the combination of $\mathbf{1 3 g}$ and $\mathrm{Zr}\left(\mathrm{NMe}_{2}\right)_{4}$ as the catalyst. Formation of piperidine 14 (entry 2) proceeded in $99 \%$ yield and $51 \%$ ee using $20 \mathrm{~mol} \%$ catalyst at $85^{\circ} \mathrm{C}$. Lowering the catalyst loading to $10 \mathrm{~mol} \%$ provided 14 in slightly lower yield but without erosion of ee. Substrates lacking the geminal dimethyl group could also be cyclized, albeit in diminished yield and ee (entries 3 and 4). Substrates containing trans-disubstituted alkenes cyclized in high yield with moderate enantioselection (entry 5). Cyclization of 2-allylaniline provided 18 in $93 \%$ yield and $70 \%$ ee as determined by GC analysis (entry 5). On a larger scale, $\mathbf{1 8}$ could be isolated in $85 \%$ yield and identical ee. As a means of corroboration, we also wished to isolate other hydroamination products. 2-Napthoyl chloride proved the most convenient derivitizing agent for this propose, providing amides of sufficient molecular weight and stability for facile isolation. Isolated yields and enantioselectivities for amides prepared by this method (entries 7 and 8) are similar to those determined by the GC method.

Although we have not yet undertaken detailed mechanistic studies of this catalytic system, we have attempted to identify the catalytically active species generated from the combination of the diphosphinic amide ligands and $\mathrm{Zr}\left(\mathrm{NMe}_{2}\right)_{4}$. Upon combination of either $\mathbf{3 c}$ or $\mathbf{1 3 g}$ and an equimolar amount of $\mathrm{Zr}\left(\mathrm{NMe}_{2}\right)_{4}$ in $d_{8}$-toluene at $25^{\circ} \mathrm{C}$, a complex mixture of compounds arose with 10 unassigned signals observed in the ${ }^{31} \mathrm{P}$ NMR spectrum. Heating this mixture at $75^{\circ} \mathrm{C}$ for $24 \mathrm{~h}$ led to the clean formation of the expected 1:1 Zr:ligand adduct $\mathbf{2 0}$ (Scheme 1), along with traces of the 2:1 adduct $\mathbf{2 1} .{ }^{14}$ The structure of $\mathbf{2 0}$ was assigned by the indicative dimethylamide signals in the ${ }^{1} \mathrm{H}$ NMR spectrum at $c a .3 .55 \mathrm{ppm}$ and a single peak in the ${ }^{31} \mathrm{P}$ 
NMR spectrum at $c a .33 \mathrm{ppm}$. Addition of substrate to in situ generated $\mathbf{2 0}$ and subsequent heating provided product at a rate similar to the rates of the reactions reported in Table 1. Heating the solution of $\mathbf{2 0}$ at $135^{\circ} \mathrm{C}$ (with or without substrate present) resulted in the slow formation of $\mathbf{2 1}$. At $150{ }^{\circ} \mathrm{C}$, in the absence of substrate, $\mathbf{2 0}$ was fully converted to $\mathbf{2 1}$ within $24 \mathrm{~h}$. The structure of 21a has been determined by X-ray crystallographic analysis (Fig 2). Both 21a and $21 g$ were catalytically inactive.

Based upon these studies, and those previously reported by our group and others, $6,7,8$ this reaction likely proceeds via a transient imidozirconium species according to the general mechanism presented in Scheme 2. Combination of $\mathbf{1 3}$ and $\mathrm{Zr}\left(\mathrm{NMe}_{2}\right)_{4}$ results in the formation of 20. Addition of substrate allows the reversible loss of dimethylamine and the formation of the imidozirconium species 22. Subsequent [2+2] cycloaddition and protonation of the resulting azametallocyclobutane $\mathbf{2 3}$ by substrate regenerates the imido species and delivers the cyclic amine product. Slow decomposition of $\mathbf{2 0}$ to $\mathbf{2 1}$ represents a pathway for catalyst decomposition. Further research designed to inhibit the latter process represents a potential avenue for further optimization of this catalyst system.

In summary, we have developed the first asymmetric alkene hydroamination catalyst based upon a neutral zirconium bis(amido) complex. This system utilizes an inexpensive zirconium precatalyst and a readily prepared diphosphinic amide ligand and provides cyclic amines in high yields and up to $80 \%$ ee. In situ preparation of the active catalyst obviates the need to isolate moisture-sensitive compounds. Studies aimed at further optimization of the ligand architecture and full elucidation of the mechanism of this transformation are ongoing.

\section{Supplementary Material}

Refer to Web version on PubMed Central for supplementary material.

\section{Acknowledgements}

We thank Mr. Jared Lewis for helpful discussions regarding experimental design. This work was supported by NIH National Institute of General Medical Science (GM-25459), a NIH-NRSA postdoctoral fellowship (GM068266) to DAW and a NSF predoctoral fellowship to MC. We are grateful to Prof. Laurel Schafer (Univ. of British Columbia) for a mutual exchange of information regarding an analogous project proceeding in her laboratory.

\section{References}

1. Gagne MR, Brard L, Conticello VP, Giardello MA, Stern CL, Marks TJ. Organometallics 1992;11:2003-2005.

2. For reviews of asymmetric hydroamination, see: (a) Togni, A.; Dorta, R.; Kollner, C.; Pioda, G. 1998, 70, 1477-1485.a Togni A, Dorta R, Kollner C, Pioda G. 1998;70:1477-1485. b Roesky PW, Muller TE. Angew Chem Int Ed 2003;42:2708-2710. c Hong S, Marks TJ. Acc Chem Res 2004;37:673-686. [PubMed: 15379583] d Hultzsch KC. Org Biomol Chem 2005;3:1819-1824. [PubMed: 15889160] e Hultzsch KC. Adv Synth Catal 2005;347:367-391. f Hii KK. Pure Appl Chem 2006;78:341-349.

3. For recent reports of hydroaminations using lanthanum and Group 3 metal complexes, see:a Kim JY, Livinghouse T. Org Lett 2005;7:1737-1739. [PubMed: 15844894] b Collin J, Daran J, Jacquet O, Schulz E, Trifonov A. Chem Eur J 2005;11:3455-3462. c Birkov DV, Hultzsch KC, Hampel F. J Am Chem Soc 2006;128:3748-3759. [PubMed: 16536549] d Riegert D, Collin J, Meddour A, Schulz E, Trifonov A. J Org Chem 2006;71:2514-2517. [PubMed: 16526807]

4. For asymmetric hydroaminations using late metal catalysts, see:a Löber O, Kawatsura M, Hartwig JF. J Am Chem Soc 2001;123:4366-4367. [PubMed: 11457216] b Patil NT, Lutete LM, Wu H, Pahadi NK, Gridnev ID, Yamamoto Y. J Org Chem 2006;71:4270-4279. [PubMed: 16709071]

5. For examples of asymmetric hydroaminations using other metals, including cationic zirconium complexes, see:a Knight PD, Munslow I, O'Shaughnessy PN, Scott P. Chem Commun 2004:894-895.

Organometallics. Author manuscript; available in PMC 2008 December 11. 
b Gribkov DV, Hultzcsh KC. Angew Chem Int Ed 2004;43:5542-5546. c Martinez PH, Hultzsch KC, Hampel F. Chem Commun 2006:2221-2223.

6. Bexrud JA, Beard JD, Leitch DC, Schafer LL. Org Lett 2005;7:1959-1962. [PubMed: 15876029]

7. Kim H, Lee PH, Livinghouse T. Chem Commun 2005:5205-5207.

8. a Ackermann L, Bergman RG. Org Lett 2002;4:1475-1478. [PubMed: 11975607] b Ackermann L, Bergman RG, Loy RN. J Am Chem Soc 2003;125:11956-11963. [PubMed: 14505417]

9. There has been one report of an asymmetric intramolecular allene hydroamination catalyzed by neutral titanium bis(amido) complexes that employed chiral aminoalcohol ligands. The maximum reported ee was 16\%. See:Hoover JM, Petersen JR, Pikul JH, Johnson AR. Organometallics 2004;23:46144620.

10. In screening efforts, ligand ( $22 \mathrm{~mol} \%$ ) and Group IV tetrakis(dimethylamide) (20 mol\%) were combined in toluene and heated to $135^{\circ} \mathrm{C}$ for $15 \mathrm{~min}$ to insure formation of ligand/metal complex. Aminoalkene 1 was then introduced, and the reaction mixture was heated with stirring for $24 \mathrm{~h}$. After acylation with trifluoroacetyl anhydride (TFAA), the product was analyzed by chiral GC.

11. The absolute stereochemistry of amide 2 was established by determination of the des-acyl piperdine using the method reported by Livinghouse using $O$-acetylmandelatic acid; see reference ${ }^{3 \mathrm{a}}$. The absolute stereochemistry of the remaining products have not been established.

12. a Jamieson JY, Schrock RR, Davis WM, Bonitatebus PJ, Zhu SS, Hoveyda AH. Organometallics 2000;19:925-930. b Ghosh AK, Chen Y. Tetrahedron Lett 1995;36:6811-6814. c Shi M, Sui W. Tetrahedron: Asymmetry 1999;10:3319-3325. d Shi M, Sui W. Chirality 2000;12:574-580. [PubMed: 10861958]

13. To our knowledge, these are the first examples of hafnium-catalyzed hydroaminations.

14. See Supporting Information for details.

15. The fact that $\mathrm{LiNMe}_{2}$ does not inhibit the reaction excludes the possibility that catalysis is due to trace acidic impurities. 

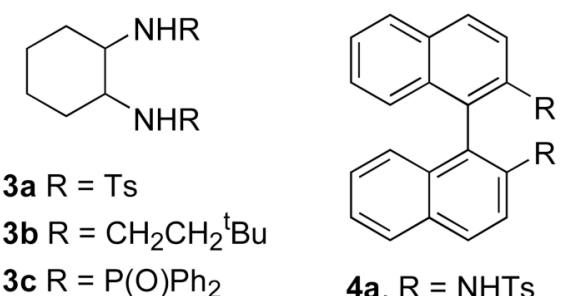

4a, $\mathrm{R}=\mathrm{NHTs}$

4b, $\mathrm{R}=\mathrm{NHSO}_{2} \mathrm{Mes}$<smiles>Cc1cc(C(C)(C)C)c(O)c(-c2c(C)c(C)cc(C(C)(C)C)c2O)c1C</smiles>

6

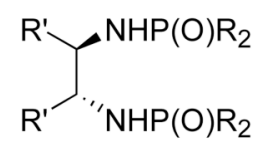

$9 \mathrm{R}^{\prime}=\mathrm{Ph}$

$10 \mathrm{R}^{\prime}=$ mesityl

$11 \mathrm{R}^{\prime}={ }^{\mathrm{t}} \mathrm{Bu}$ 4c, $\mathrm{R}=\mathrm{NH}^{\mathrm{i}} \mathrm{Pr}$

4d, $\mathrm{R}=\mathrm{OH}$<smiles>[NH3+]C1c2ccccc2C[C@@H]1O</smiles>

7<smiles></smiles>

5a, $\mathrm{Ar}=\mathrm{Ph}$

5b, $\mathrm{Ar}=\mathrm{C}_{10} \mathrm{H}_{9}$<smiles>PNc1ccc2c(c1-c1c(Nc3ccccc3P)ccc3c1CCCC3)CCCC2</smiles>

Figure 1.

Structures of ligands examined. 


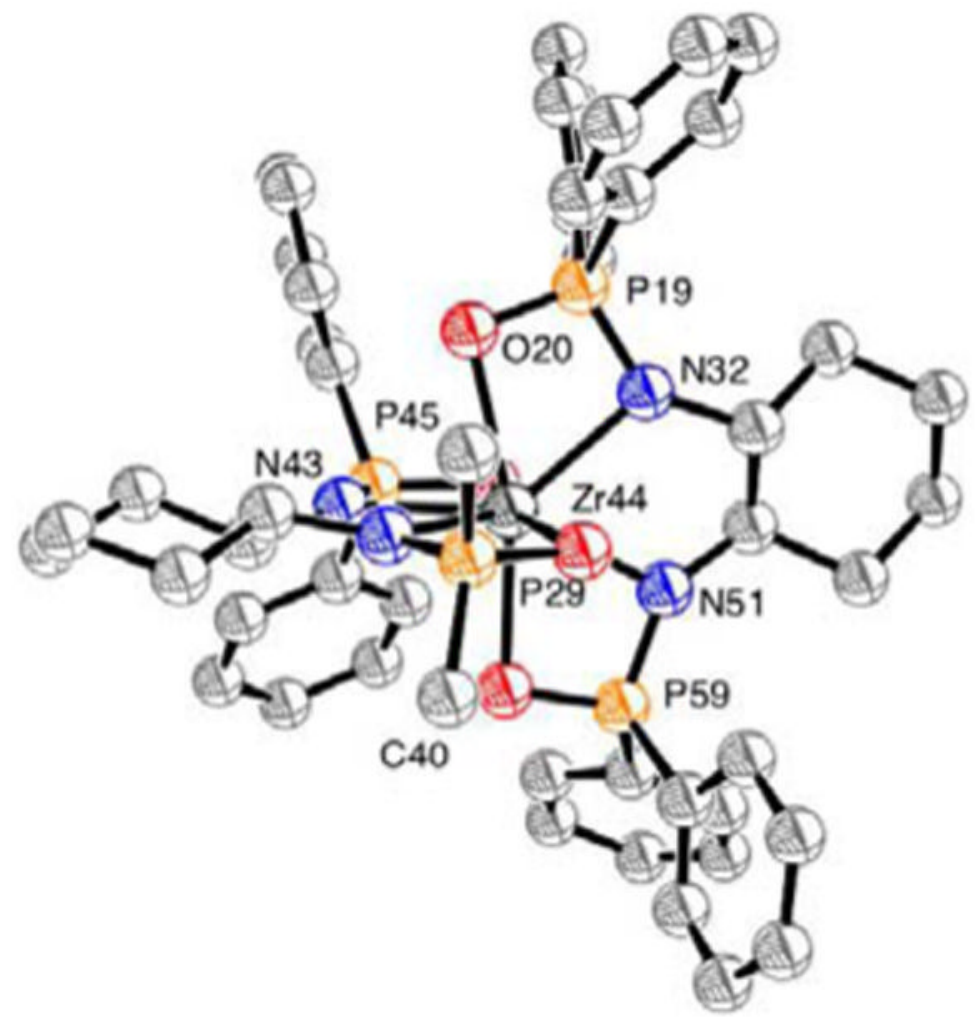

Figure 2.

ORTEP representation of the solid state structure of 21a. Arenes connected to P29 have been truncated for clarity. Thermal ellipsoids are shown at 50\% probability. 


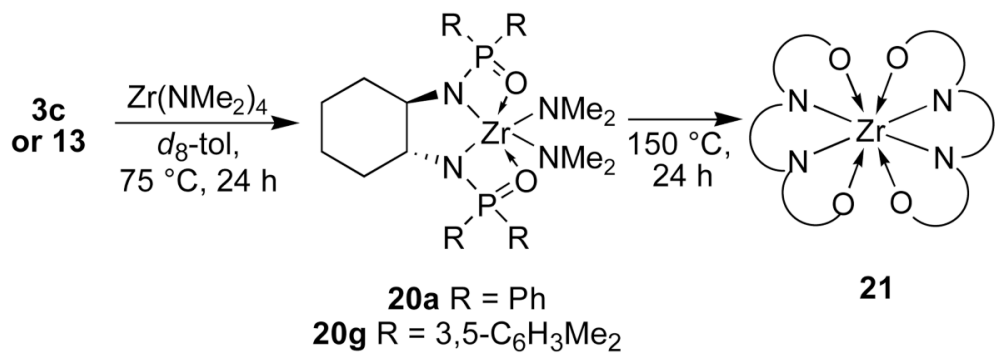

Scheme 1.

Products from the reaction of diphosphinic amide ligands and $\mathrm{Zr}\left(\mathrm{NMe}_{2}\right)_{4}$. 


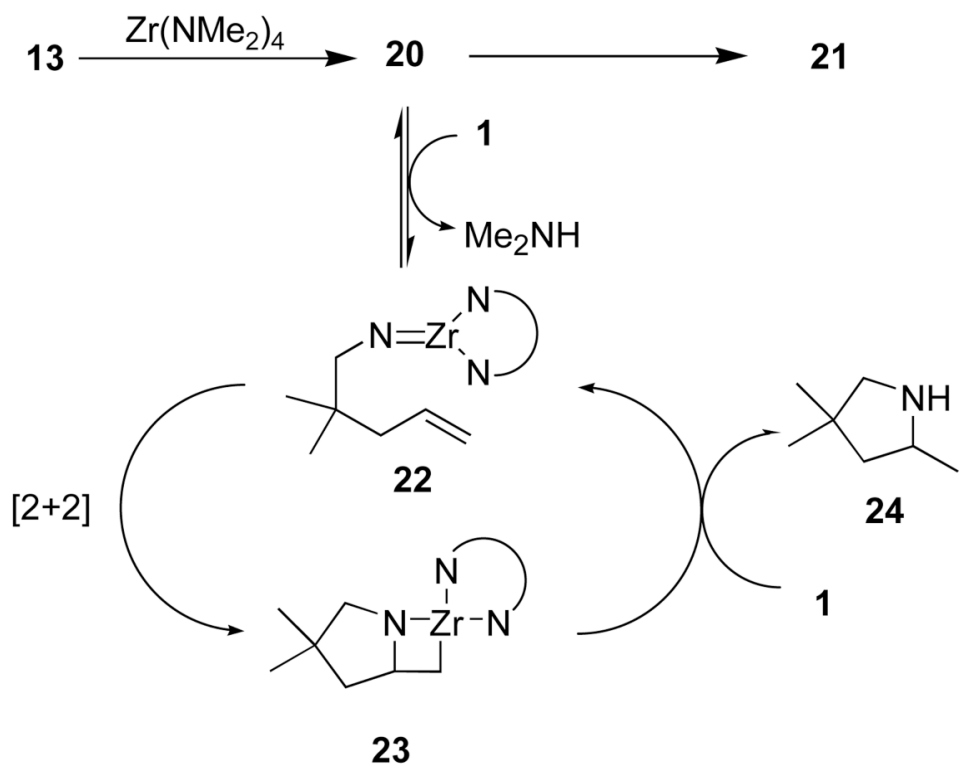

Scheme 2.

Proposed catalytic cycle and catalyst decomposition. 
Table 1

Results from initial screen of ligands for conversion of $\mathbf{1}$ to $\mathbf{2}$.

\begin{tabular}{|c|c|c|c|c|}
\hline \multirow[t]{2}{*}{ entry } & \multirow[t]{2}{*}{ ligand } & \multicolumn{3}{|c|}{$\mathrm{M}\left(\mathrm{NMe}_{2}\right)_{4}, \%$ conversion $(\%$ ee $)$} \\
\hline & & $\mathbf{T i}$ & $\mathbf{Z r}$ & Hf \\
\hline 1 & none & $97(0)$ & $80(0)$ & $88(0)$ \\
\hline 2 & $R, R-3 \mathbf{a}$ & $<5(\mathrm{n} / \mathrm{a})$ & $92(21)$ & $94(13)$ \\
\hline 3 & $R-4 a$ & $<5(\mathrm{n} / \mathrm{a})$ & $89(18)^{a}$ & $59(30)^{a}$ \\
\hline 4 & $R-4 b$ & $<5(\mathrm{n} / \mathrm{a})$ & $90(23)^{a}$ & $24(26)^{a}$ \\
\hline 5 & $S, S-3 \mathrm{~b}$ & $97(9)$ & $94(20)$ & $94(13)$ \\
\hline 6 & $R-4 \mathrm{c}$ & $88(<5)$ & $87(<5)$ & $87(<5)$ \\
\hline 5 & $S-4 \mathrm{~d}$ & $<5(\mathrm{n} / \mathrm{a})$ & $97(<5)$ & $63(19)$ \\
\hline 6 & $\begin{array}{c}5-40 \\
5 a\end{array}$ & $59(13)$ & $97(24)^{a}$ & $98(9)^{a}$ \\
\hline 7 & $5 \mathbf{b}$ & $52(6)^{a}$ & $98(27)^{a}$ & $99(12)^{a}$ \\
\hline 8 & 6 & $84(26)$ & $96(<5)$ & $98(7)$ \\
\hline 9 & 7 & $<5(\mathrm{n} / \mathrm{a})$ & $<5(\mathrm{n} / \mathrm{a})$ & $<5(\mathrm{n} / \mathrm{a})$ \\
\hline 10 & 8 & $95(15)^{a}$ & $99(34)^{a}$ & $73(18)^{a}$ \\
\hline 11 & $R, R-3 \mathrm{c}$ & $8(<5)$ & $96(67)$ & $76(58)$ \\
\hline
\end{tabular}

Conditions: $22 \mathrm{~mol} \%$ ligand, $20 \mathrm{~mol} \% \mathrm{M}\left(\mathrm{NMe}_{2}\right) 4,135^{\circ} \mathrm{C}$, tol, $24 \mathrm{~h}$; ligand and $\mathrm{M}(\mathrm{NMe} 2) 4$ were pre-heated $135^{\circ} \mathrm{C}$ for 15 min prior to introduction of 1. Unless otherwise indicated, the (S)-enantiomer of product predominate. Conversion was determined using chiral GC by comparison of the sum of the enantiomers of product to the remaining starting material.

$a_{\text {The }(R) \text {-enantiomer was predominate. }}$ 
Table 2

Results from the use of diphosphinic amide ligands with $\mathrm{Zr}\left(\mathrm{NMe}_{2}\right)_{4}$ in the conversion of $\mathbf{1}$ to 2.

\begin{tabular}{|c|c|c|c|c|}
\hline entry & ligand & $\mathbf{R}$ & $\%$ conversion & $\%$ ee \\
\hline 1 & $3 c$ & $\mathrm{Ph}$ & 98 & 67 \\
\hline 2 & 9 & $\mathrm{Ph}$ & 96 & 50 \\
\hline 3 & 10 & $\mathrm{Ph}$ & 95 & 55 \\
\hline 4 & 11 & $\mathrm{Ph}$ & $<1$ & $\mathrm{n} / \mathrm{a}$ \\
\hline 5 & 12 & $\mathrm{Ph}$ & 46 & 16 \\
\hline 6 & $13 \mathbf{a}$ & $o$-tol & $<1$ & $\mathrm{n} / \mathrm{a}$ \\
\hline 7 & $13 \mathrm{~b}$ & $3,5-\mathrm{C}_{6} \mathrm{H}_{3}\left(\mathrm{CF}_{3}\right)_{2}$ & decomp & $\mathrm{n} / \mathrm{a}$ \\
\hline 8 & $13 \mathrm{c}$ & $3,5-\mathrm{C}_{6} \mathrm{H}_{3} \mathrm{~F}_{2}$ & 92 & 63 \\
\hline 9 & 13d & $3,5-\mathrm{C}_{6} \mathrm{H}_{3}(\mathrm{OMe})_{2}$ & 99 & 68 \\
\hline 10 & $13 e$ & $p-\mathrm{C}_{6} \mathrm{H}_{4}(\mathrm{OMe})$ & 99 & 70 \\
\hline 11 & 13f & $o-\mathrm{C}_{6} \mathrm{H}_{4}(\mathrm{OMe})$ & 95 & 76 \\
\hline 12 & $13 g$ & $3,5-\mathrm{C}_{6} \mathrm{H}_{3} \mathrm{Me}_{2}$ & 99 & 75 \\
\hline 13 & $13 \mathrm{~h}$ & $3,5-\mathrm{C}_{6} \mathrm{H}_{3}\left({ }^{\mathrm{t}} \mathrm{Bu}\right)_{2}$ & 98 & 62 \\
\hline
\end{tabular}

Conditions: $22 \mathrm{~mol} \%$ ligand, $20 \mathrm{~mol} \% \mathrm{Zr}\left(\mathrm{NMe}_{2}\right) 4,135^{\circ} \mathrm{C}$, tol, $24 \mathrm{~h}$; ligand and $\mathrm{Zr}(\mathrm{NMe} 2) 4$ were pre-heated $135^{\circ} \mathrm{C}$ for 15 min prior to introduction of 1. In all cases, the ligand was the $(R, R)$-enantiomer and the $(S)$-enantiomer of $\mathbf{2}$ was predominate in the product. Conversion was determined using chiral $\mathrm{GC}$ by comparison of the sum of the enantiomers of product to the remaining starting material. 


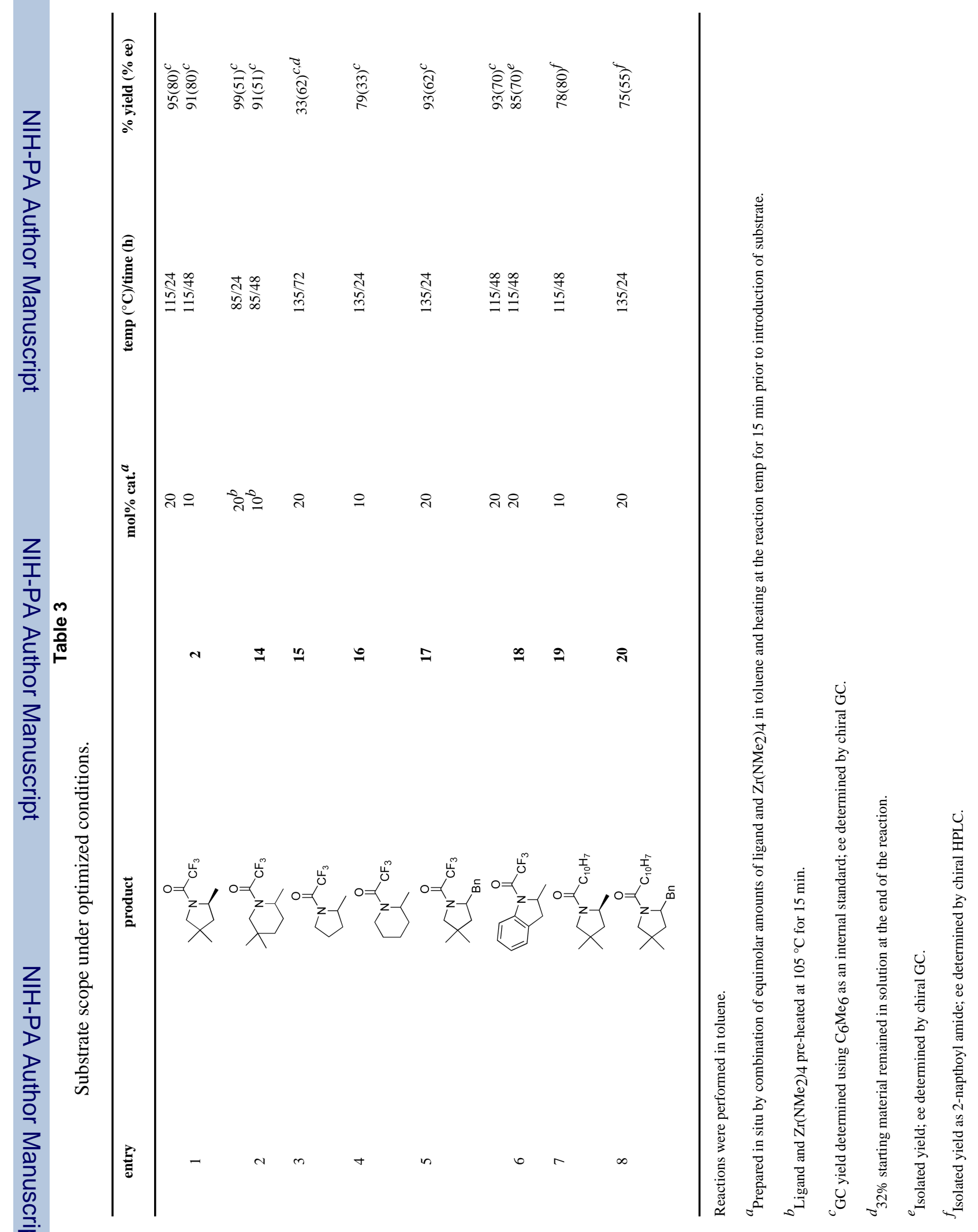

